\title{
Quincy Wright on war and peace: a statistical overview and selected bibliography
}

\author{
CLINTON F. FINK \\ Center for Research on Conflict Resolution, University of Michigan
}

and CHRISTOPHER WRIGHT

Institute for the Study of Science in Human Affairs, Columbia University

Quincy Wright sought to bring the world together, and in the process communicated with many parts of it. This is reflected in the number and diversity of his audiences. A fiftythree page bibliography of his published works lists nearly eleven hundred items (many of which are reprints or translations of others) including books, chapters and introductions in books, journal articles, book reviews, encyclopedia articles, and published radio broadcasts. It spans nearly six decades, beginning with a review in 1913 of Edward Corwin's book, National Supremacy, and ending with five articles and a monograph appearing in 1970. Even this is incomplete, since it includes only a handful of Wright's numerous letters published in newspapers, magazines, and scholarly journals. ${ }^{1}$

Space limitations preclude reproducing here the entire bibliography. Instead, a list of about 145 items, selected for their relevance to the main research interests of the Journal of Conflict Resolution, is presented below in chrono-

\footnotetext{
'A comprehensive collection of Quincy Wright's work, together with his unpublished correspondence and papers, is being established by the Curator of Special Collections in the University of Chicago Library.
}

logical order. Some statistics describing the whole bibliography may help put the selected list in perspective. Table 1 shows the decadeby-decade frequency of items in each of the six main categories of the complete bibliography, of which only the first three are represented in the selected bibliography.

Since they are so few, the twenty-one items listed under "books" are all included below in order to show the full range of Wright's major contributions. The second category of Table 1 , "chapters and introductions in books", can be further broken down (see Table 2). Most of the Chicago books were in the Lecture Series of the Harris Foundation on International Relations. The "introductions" also include a number of prefaces, forewords, comments, and remarks for various symposia and conference proceedings. The "reprinted articles" are those which are easily recognized or explicitly identified as such, while the "other papers" appear to be mostly new items prepared especially for particular conferences, symposia, and Festschrift volumes. None of the first three subcategories is listed below, but thirtynine of the "other papers" are included.

The 398 "journal articles" exhibit the full range of Wright's professional interests and audiences. Their overall distribution across 
TABLE 1

FREQUENCY OF TYPES OF PUBLICATIONS BY DECADE

\begin{tabular}{lccccccr}
\hline \hline \multicolumn{1}{c}{ Publication } & $1911-20$ & $1921-30$ & $1931-40$ & $1941-50$ & $1951-60$ & $1961-70$ & Total \\
\hline Books & 1 & 4 & 2 & 2 & 7 & 5 & 21 \\
Chapters and introductions & 2 & 12 & 15 & 29 & 47 & 44 & 149 \\
Journal articles & 17 & 69 & 66 & 113 & 87 & 46 & 398 \\
Book reviews & 10 & 76 & 78 & 73 & 48 & 43 & 328 \\
Encyclopedia articles & - & - & 3 & 20 & 88 & 35 & 146 \\
Broadcasts & - & - & 16 & 27 & 12 & - & 55 \\
All categories & 30 & 161 & 180 & 264 & 289 & 173 & 1097 \\
\hline
\end{tabular}

TABLE 2

TYPES OF CHAPTERS AND INTRODUCTIONS IN BOOKS BY DECADE

\begin{tabular}{lccccccc}
\hline \hline \multicolumn{1}{c}{ Publication } & $1911-20$ & $1921-30$ & $1931-40$ & $1941-50$ & $1951-60$ & $1961-70$ & Total \\
\hline $\begin{array}{l}\text { Introductions: } \\
\quad \text { University of Chicago Press }\end{array}$ & - & 11 & 5 & 4 & 3 & - & 23 \\
$\quad \begin{array}{l}\text { Other publishers } \\
\text { Chapters: }\end{array}$ & - & - & 6 & 3 & 12 & 8 & 29 \\
$\quad \begin{array}{l}\text { Reprinted articles } \\
\text { Other papers }\end{array}$ & - & - & 1 & -7 & 7 & 13 & 21 \\
\hline
\end{tabular}

TABLE 3

DISTRIBUTION OF ARTICLES ACROSS JOURNALS BY DECADE

\begin{tabular}{|c|c|c|c|c|c|c|c|}
\hline Periodical & $1911-20$ & $1921-30$ & $1931-40$ & $1941-50$ & $1951-60$ & $1961-70$ & Total \\
\hline $\begin{array}{l}\text { Law: } \\
\quad \text { American Journal of International Law } \\
\text { Proceedings, American Society of }\end{array}$ & 8 & 23 & 21 & 22 & 13 & 6 & ${ }^{154} 93$ \\
\hline $\begin{array}{l}\text { International Law } \\
32 \text { other law journals }\end{array}$ & $\overline{2}$ & $\begin{array}{l}3 \\
8\end{array}$ & $\begin{array}{l}1 \\
5\end{array}$ & $\begin{array}{l}3 \\
7\end{array}$ & $\begin{array}{l}8 \\
8\end{array}$ & $\begin{array}{r}4 \\
12\end{array}$ & $\begin{array}{l}19 \\
42\end{array}$ \\
\hline \multirow{3}{*}{$\begin{array}{l}\text { International relations: } \\
\text { Chicago Council on Foreign Rela- } \\
\text { tions (Publications, Foreign Notes, } \\
\text { World Events) } \\
\text { International Conciliation } \\
22 \text { other international relations and } \\
\text { peace research journals }\end{array}$} & & & & & & & 71 \\
\hline & - & $\begin{array}{r}14 \\
2\end{array}$ & - & $\begin{array}{r}6 \\
10\end{array}$ & $\begin{array}{l}3 \\
5\end{array}$ & - & $\begin{array}{l}23 \\
17\end{array}$ \\
\hline & 1 & 2 & 4 & 4 & 12 & 8 & 32 \\
\hline \multirow[t]{2}{*}{$\begin{array}{l}\text { General social science: } \\
\text { American Political Science Review } \\
11 \text { other political science journals } \\
19 \text { other social science and history } \\
\text { journals }\end{array}$} & 2 & $\begin{array}{l}5 \\
2\end{array}$ & $\begin{array}{l}2 \\
4\end{array}$ & $\begin{array}{l}3 \\
4\end{array}$ & $\overline{4}$ & $\overline{6}$ & $\begin{array}{r}60 \\
12 \\
20\end{array}$ \\
\hline & - & 7 & 2 & 6 & 11 & 2 & 28 \\
\hline Miscellaneous ( 80 other periodicals) & 4 & 5 & 24 & 48 & 24 & 8 & 113 \\
\hline
\end{tabular}


journals is quite skewed, fitting a typical $j$ curve. Five periodicals contain more than ten items each, and together these account for 164 articles (41 percent of the total). The remainder are scattered widely in 164 different periodicals. Table 3 shows the time distribution of articles grouped by types of periodicals. Obviously the largest and most persistent stream of contributions is in the field of international law, with 41 percent of the articles appearing in law journals. By a rough estimate, these would also account for considerably more than half of the published pages among journal articles. Another 18 percent appear in international relations journals, and 15 percent are in general political science, history, and social science journals. The remainder are aimed at a few other scholarly groups and a great variety of nonscholarly audiences. They are mostly short articles appearing in various non-academic newspapers, magazines, and pamphlet series with specific regional, organizational, religious, or political affiliations; they also include such items as a pamphlet prepared for the League of Nations exhibit at the Chicago World's Fair, and four appearances at congressional hearings on foreign relations. These miscellaneous articles are distributed across eighty periodicals (nearly half the total number) and constitute
28 percent of the articles, but probably contain less than 10 percent of the total published pages in journals. The selected bibliography contains eighty-five items drawn almost exclusively from the international relations and general social science journals.

The book reviews (not included below) are less scattered, being aimed mostly at scholarly and scientific audiences. About $\mathbf{4 0}$ percent of the 328 book reviews ${ }^{2}$ appear in law journals. Another 43 percent appear in general social science and history journals, including a few in international relations and peace research. The rest are scattered in a variety of regional or local magazines, except for the past decade when they appear mostly in Science and the Bulletin of the Atomic Scientists. The time distribution of these reviews in various periodicals is shown in Table 4.

Finally the encyclopedia articles and radio broadcasts reflect Wright's role as an expert communicating to the general public. The three early articles appear in the Encyclopedia of the Social Sciences (1930-34), but most of the others are in various editions and year-

\footnotetext{
${ }^{2}$ This number refers to the actual number of books reviewed, rather than the number of separate review articles.
}

TABLE 4

DISTRIBUTION OF BOOK REVIEWS ACROSS JOURNALS BY DECADE

\begin{tabular}{|c|c|c|c|c|c|c|c|}
\hline Periodical & $1911-20$ & $1921-30$ & $1931-40$ & $1941-50$ & $1951-60$ & $1961-70$ & Total \\
\hline $\begin{array}{l}\text { Law: } \\
\text { American Journal of International Law } \\
18 \text { other law journals }\end{array}$ & $\begin{array}{l}0 \\
1\end{array}$ & $\begin{array}{l}14 \\
17\end{array}$ & $\begin{array}{l}13 \\
12\end{array}$ & $\begin{array}{l}15 \\
19\end{array}$ & $\begin{array}{r}9 \\
11\end{array}$ & $\begin{array}{r}18 \\
4\end{array}$ & $\begin{array}{r}133 \\
69 \\
64\end{array}$ \\
\hline $\begin{array}{l}\text { Social science and history: } \\
\text { American Journal of Sociology } \\
\text { American Political Science Review } \\
\text { Annals (American Academy of } \\
\text { Political and Social Science) } \\
6 \text { other political science journals } \\
8 \text { other social science and history } \\
\text { journals }\end{array}$ & $\begin{array}{l}0 \\
0\end{array}$ & $\begin{array}{l}17 \\
19\end{array}$ & $\begin{array}{r}17 \\
6\end{array}$ & $\begin{array}{l}3 \\
6\end{array}$ & $\begin{array}{l}5 \\
5\end{array}$ & $\begin{array}{l}0 \\
2 \\
2 \\
4\end{array}$ & $\begin{array}{r}141 \\
40 \\
35\end{array}$ \\
\hline Miscellaneous (27 other periodicals) & 3 & $\mathbf{0}$ & 16 & 15 & 7 & 13 & 54 \\
\hline
\end{tabular}


TABLE 5

CURRICULUM VITAE OF QUINCY WRIGHT

Birth

December 28, 1890, in Medford, Massachusetts

Degrees

A.B. Lombard College, Galesburg, Ill., 1912

A.M. University of Illinois, 1913

Ph.D. University of Illinois, 1915

LL.D. Lombard College, 1923

LL.D. K nox College, 1959

LL.D. University of Illinois, 1967

Academic appointments

Research Fellow, University of Pennsylvania, 1915-16

Assistant and Instructor in International Law, Harvard, 1916-19

Assistant Professor, Political Science, University of Minnesota, 1919-21

Associate Professor, Political Science, University of Minnesota, 1921-22

Professor, Political Science, University of Minnesota, 1922-23

Professor, Political Science, University of Chicago, 1923-3

Professor, International Law, University of Chicago, 1931-56

Visiting Research Scholar, Carnegie Endowment for International Peace, New York, 1956-57

Professor, Foreign Affairs, University of Virginia, 1958-61

Appointments as Visiting Professor

Brookings Institution, 1929

Tsing Hua University, Peking, China, 1929

Seminar on Latin American Affairs, Mexico City, 1931

University Institute of Advanced International Studies, Geneva, Switzerland, 1934, 1938

Turkish Institute of International Law, 1949

Inter-American Academy of Comparative and International Law, Havana, Cuba, 1955

Indian School of International Studies, Delhi, India, 1957-58, 1962

Academy of International Law, The Hague, Netherlands, 1959

University of Manchester, England, 1961

Columbia University, 1962-63

Seminar for West Indian Diplomats, Barbados, 1963

American University of Cairo, 1964

University of Ankara, Turkey, 1964

Makerere University College, Kampala, Uganda, 1964

Dag Hammarskold, Seminar for African Diplomats, Lusaka, Zambia, 1964

Seminar, Syracuse University, 1965

Cornell University, 1965

Rice University, 1966

University of Michigan, 1968

Other appointments

Special Assistant in International Law, U.S. Navy Department, 1918, 1921

Consultant to Foreign Economic Administration and Department of State, 1943-44

Technical Adviser to American Member, International Military Tribunal, Nuremberg, 1945

Consultant to UNESCO, 1949

Consultant to U.S. High Commissioner in Germany, 1949-50

Trustee, Knox College

Director, Foreign Bondholders Protective Council, 1936-67

Professional Affiliations

Fellow, American Academy of Arts and Sciences

Member, American Philosophical Society

Member, Institut de droit international

Member, International Law Association

American Political Science Association (President, 1949)

International Political Science Association (President, 1950)

American Society of International Law (President, 1956)

American Association of University Professors (President, 1944-46)

Institute of Pacific Relations (Conferences, Honolulu, 1927; Kyoto, 1929; Banff, 1933; Yosemite, 1936;

Virginia Beach, 1939; Lahore, 1958)

Conference on Science, Philosophy and Religion

U.N. Association (President, Chicago branch, 1953)

Commission to Study the Organization of Peace (Chairman, Drafting Committee, 1953-59)

Council for the Study of Mankind (Chairman, Executive Committee, 1958-1965)

Prize awards

American Philosophical Society, 1921

Guggenheim Fellow (Middle East), 1925

Western Political Quarterly, 1951

Institute for Social Research, Oslo, Norway, 1952

American Council of Learned Societies, 1961

Phi Beta Kappa, University of Virginia, 1961

Death

October 17, 1970, in Charlottesville, Virginia 


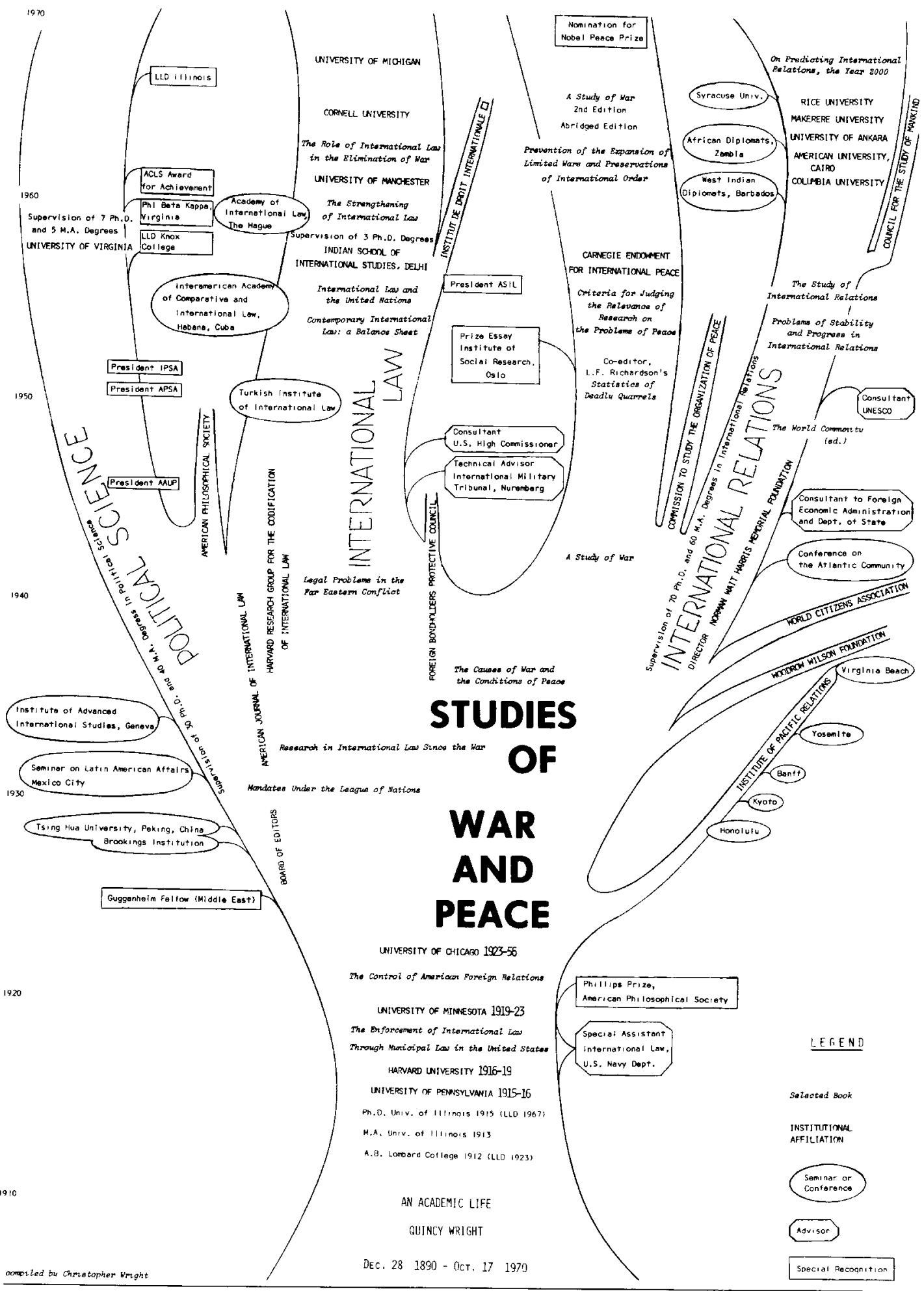

FIG. 1. An Academic life of Quincy Wright. 
books of the Americana $(\mathrm{n}=87)$ and the Britannica $(\mathrm{n}=38)$ beginning in 1945 . They deal primarily with topics in international law and developments in US foreign policy, but there is a scattering of other topics including "Theory of War" in the 1970 Britannica. On the other hand, the radio broadcasts (mostly panel discussions on the Chicago Round Table and Northwestern Reviewing Stand from 1938 to 1955) deal almost exclusively with current international events and their foreign policy implications.

The international character of Wright's audiences is also highly relevant to his career. Unfortunately, it is difficult to assess this from the bibliography. Only a small fraction of the articles (approximately 12 percent) and of the book reviews ( 1 percent) appear in international or foreign publications. But this clearly underestimates the relative size of his international audience, since many of the US journals in which he published enjoy substantial foreign circulation. Furthermore, it does not take into account the extent to which his works have been translated into various languages. (Christopher Wright is currently preparing an appendix to the bibliography, listing translations and other items such as book reviews in foreign journals which have recently come to light.) Perhaps a more accurate estimate can be obtained from a secondary bibliography which lists theses prepared under his supervision. From 1926 through 1968 , a total of 111 students completed doctoral dissertations with Quincy Wright as their principal advisor. Of these, nearly a quarter ( 23 percent) were citizens of other countries (fourteen Asians, five Europeans, three Middle Easterners, three Canadians, and one African). The several years that he spent as a visiting professor at foreign institutions provide another indication of the international scope of his activities (see the curriculum vitae in Table 5).

The above analyses provide a rough overview of the number and forms of his writings, and of the interdisciplinary and international distribution of his audiences. The selected bibliography below conveys considerable information about the range of topics he discussed. Both kinds of information are conveyed graphically in Figure 1, which attempts to show the main outlines of Wright's career in its intellectual, bibliographic, institutional, and international aspects. Together the data we have presented give a clear indication of the immense task which awaits the intellectual biographer of Quincy Wright.

\section{Selected Bibliography}

\section{BOOKS}

The Enforcement of International Law Through Muncipal Law in the United States; University of Illinois, Studies in the Social Sciences, V, March, 1916. Pp. 264. (Reprinted by Johnson Reprint, 1969.)

The Control of the Foreign Relations of the United States: The Relative Rights Duties, and Responsibilities of the President, the Senate and the House, and of the Judiciary in Theory and in Practice. (Henry M. Phillips Prize Essay awarded April 23, 1921 by the American Philosophical Society) Proceedings of the American Philosophical Society, XL, Philadelphia, 1921. Pp. 99-455.

The Control of American Foreign Relations; New York, Macmillan, 1922. Pp. xxvi + 412 (Reprint of Prize Essay, Am. Phil. Soc., 1921).

Mandates Under the League of Nations; Chicago, University of Chicago Press, 1930. Pp. xvi +726.

Research in International Law Since the War; Washington, D.C., Carnegie Endowment for International Peace, 1930. Pp. 58.

The Causes of War and the Conditions of Peace; London and New York, Longmans, Green, 1935. Pp. xi +148 .

The Existing Legal Situation As It Relates to the Conflict in the Far East; New York, Institute of Pacific Relations, 1939. Pp. 129

Legal Problems in the Far Eastern Conflict (with Edwin M. Borchard, H. Lauterpacht and Phoebe Morrison); New York, Institute of Pacific Relations, 1941. Pp. vii +211 .

A Study of War; 2 vols., University of Chicago Press, 1942, vol. 1, xxiv + 678; vol. 2, xviii + 679-1552. 
Problems of Stability and Progress in International Relations; Berkeley, University of California Press, 1954. Pp. xiv +378.

Criteria for Judging the Relevance of Researches on the Problems of Peace, (Research of Peace Essays: Results of a Prize Contest) Institute for Social Research, Oslo, Norway, (Amsterdam, North Holland Publishing, 1954). Pp. 1-94.

Contemporary International Law: a Balance Sheet; New York, Doubleday, 1955. Pp. $x+65$.

The Study of International Relations; New York, Appleton-Century-Crofts, 1955. Pp. xii +642 .

International Law and the United Nations; Academia Inter-Americana de Derecho Comparado e Internacional, Cursos Monograficos, V (Havana, 1956). Pp. 313-433.

The Strengthening of International Law; Academy of International Law, The Hague, Recueil des cours, 1959 (A. W. Sythoff, Leyden, 1960). Pp. 295.

International Law and the United Nations; Bombay and New York, Asia Publishing House, 1960. Pp. $\mathrm{X}+134$.

Prevention of the Expansion of Limited Wars and Preservation of International Order with Especial Reference to the Role of Seaborne Weapons Systems; China Lake, Cal., Studies in Deterrence, U.S. Naval Ordnance Test Station, May, 1961. Pp. vi +126.

The Role of International Law in the Elimination of War; Manchester, England, Manchester University Press, and New York, Oceana Publications, 1961. Pp. viii +119.

A Study of War; Second Edition, with Commentary on Wars since 1942, University of Chicago Press, 1965. Pp. xlii + 1637.

A Study of War; abridged by Louise Leonard Wright, University of Chicago Press, 1964, and Phoenix Books (paperbound), 1965. Pp. xiv + 451 .

On Predicting International Relations. The Year 2000. Social Science Foundation and Graduate School of International Relations, University of Denver Monograph Series in World Affairs, vol. 7, no. 1, 1969-70 series. Pp. 42.

\section{ARTICLES AND CHAPTERS}

\section{9}

"Effects of the League of Nations Covenant," $A \mathrm{~m}$. Pol. Sci. Rev., XIII (Nov. 1919), 556-576.

'Abbreviations used in this section are: $A m . J$. Soc is American Journal of Sociology: Am. Pol.
1921

"The Control of Foreign Relations," $\mathrm{Am}$. Pol. Sci. Rev., XV (Feb. 1921), 1-26.

"Limitation of Armament," Institute of International Education, International Relations Clubs, Syllabus, (Nov. 1921), No. xii, 1-38.

\section{3}

"Responsibility of the Teacher With Respect to Foreign Affairs," Harvard University Summer School, Second Annual Conference on Social Studies, (1923), 691-703.

\section{6}

"The Government of Iraq," Am. Pol. Sci. Rev., XX (1926), 743-769.

"The Palestine Problem," Political Science Quarterly, XLI (1926), 384-412.

1927

"An Analytical Approach to the Subject of WorldPolitics in Teaching and Research," $\mathrm{Am}$. Pol. Sci. Rev., XXI (1927), 296-299.

\section{8}

"American Foreign Policy, Domestic Control," in Charles P. Howland, ed., Survey of American Foreign Relations, New Haven, Council on Foreign Relations, 1928, 83-148.

"The Future of Neutrality," International Conciliation, (September 1928), No. 242, 1-98.

"The Slavery Convention of Geneva," (with A. L. Wrnshuis and J. P. Chamberlain), International Conciliation (Jan. 1928), No. 236, 1-67.

\section{9}

"The Mandates System and Public Opinion," Southwestern Political and Social Science Quarterly, IX (1929), 369-406.

\section{0}

"The Kyoto Conference of the Institute of Pacific Relations," Am. Pol. Sci. Rev., XXIV (1930), 451-457.

"Foreign Policy," Am. J. Soc., XXXV (1930), 910-922.

Sci. Rev. is American Political Science Review; and Annals is Annals, American Academy of Political and Social Science. 
1932

"Manchurian Crisis," Am. Pol. Sci. Rev.. XXVI (1932), 45-76.

\section{3}

"National Attitudes on the Far Eastern Controversy," (with James T. Russell), Am. Pol. Sci. Rev., XXVII (1933), 555-576.

\section{4}

"Is the League of Nations the Road to Peace?" Political Quarterly, London, V (1934), 92-106.

"Some Political Considerations in Formulating an International Economics Policy," in Report of the Commission of Inquiry into National Policy in International Economic Relations. Minneapolis, University of Minnesota Press, 1934, 281-290.

\section{5}

"American View of Far Eastern Problems," International Affairs, London, XIV (1935), 69-82.

\section{6}

"National Sovereignty and Collective Security," Annals, CLXXXVI (1936), 94-104.

"Population and International Relations," Annals, CLXXXVIII (1936), 318-328.

\section{8}

"The Causation and Control of War," American Sociological Review. III (August 1938), 461-474.

\section{9}

"The Causes of War and the Conditions of Peace," in George Murray, ed., The Popular Educator. (1939), No. 17, 1473-1482.

"International Law," in F. J. Brown, Charles Hodges, and Joseph S. Roucek, Contemporary World Politics. New York, John Wiley, 1939. 392-410.

"Political Activities of the League of Nations," Politica. London, IV (1939), 197-219.

\section{1}

"Academic Freedom and World Politics," Bulletin. American Association of University Professors. XXVII (Feb. 1941), 14-17.

"Inventions and War," Scientific Monthly, LIII (Dec. 1941), 526-541.
"International Law and the Totalitarian States," Am. Pol. Sci. Rev., XXXV (Aug. 194l), $738-743$.

"International Law and the World Order" in W. H. C. Laves, ed., The Foundations of a More Stable World Order, Harris Foundation Lectures, University of Chicago Press, 1941, 107-136.

"Peace and Political International Organization," "Fundamental Problems of International Organization," in Preliminary Report and Monographs. Commission to Study the Organization of Peace. International Conciliation, (A pril 1941), No. 369, 454-492.

\section{2}

"The Future of the Near East," in Philip Ireland, ed., The Near East, Problems and Prospects, Harris Foundation Lectures, University of Chicago Press, 1942, 177-217.

"The Historic Circumstances of Enduring Peace," Annual Report of the American Historical Association, Ill (1942), 361-373.

"International Justice," in H. Robinson et al., Toward International Organization. New York, Harpers, 1942, 139-161.

"Political Conditions of the Period of Transition," in Second Report and Monographs, Commission to Study the Organization of Peace, International Conciliation, (April 1942), No. 379, 264-299.

\section{3}

"Human Rights and the World Order," Third Report and Monographs. Commission to Study the Organization of Peace, International Conciliation. (April 1943), No. 389, 238-262.

\section{4}

"The Balance of Power" and "Population Trends and International Relations," in Hans W. Weigert and Vilhjalmur Stefansson, eds., Compass of the World, A Symposium of Political Geography, New York, Macmillan, 1944.

"The Legal Problem," in George B. DeHuszar, ed., New Perspectives on Peace. University of Chicago Press, 1944, 143-161.

"National Security and International Police," in Julia E. Johnson, ed., International Police Force, New York, 1944, 7-14.

"Peace Problems of Today and Yesterday," $\mathrm{Am}$. Pol. Sci. Rev. XXXVIII (June 1943), 512-521; Indiana Historical Bulletin. XXI (Jan. 1944), 6679.

"Security and World Organization," (with T. P. Wright), 4th Report of Commission to Study the 
Organization of Peace, International Conciliation. (June 1944), No. 396, 30-61.

"The Social Sciences and Policy Formation," in Approaches to World Peace, 4th Symposium on Science, Philosophy and Religion, New York, Harper, 1944.

"What is a University," Presidential Address, Bulletin, American Association of University Professors, XXX (Summer 1944), 167-175.

\section{5}

"Essential Human Rights in the Far East," Far Eastern Survey, American Council, Institute of Pacific Relations, XIV (March 14, 1945), 53-55.

"Fundamental Problems of Peace Making," in Lyman Bryson, Louis Finkelstein, and Robert $\mathbf{M}$. Maclver, eds., Approaches to National Unity. Fifth Symposium on Science, Philosophy and Religion, New York, Harper, 1945, 743-762.

"The International Regulation of the Air," American Economic Review, Proc. Am. Ec. Assoc., XXXV (May 1945), 143-148.

"World Order Within our Grasp," in Gardner Murphy, ed., Human Nature and Enduring Peace, 3rd Year Book of the Society for the Psychological Study of Social Issues, Cambridge, $1945,230-235,450-451,460$.

\section{6}

"Accomplishments and Expectations of World Organization," Yale Law Journal, LV (August 1946), 870-888.

"Aviation and World Politics," Air Affairs, I (Sept. 1946), 97-108.

"Making the United Nations Work," The Review of Politics, VIII (Oct. 1946), 528-532.

\section{7}

"The Effect of the Atomic Bomb on World Politics," Air Affairs, I (March 1947), 383 399.

"The Relation of Universal Culture to Power Politics," in Lyman Bryson, Louis Finkelstein and R. M. Maclver, eds., Conflicts of Power in Modern Culture, Seventh Conference on Science, Philosophy and Religion, New York, Harper, 1947, 597-603.

"The Rights of Man," United Nations Weekly Bulletin, III (Dec. 9, 1947), 777-781. [Trans. Les Droit de l'homme, Nations Unies, Bulletin hebdomadaire, III (Dec. 9, 1947), 790-794; Nacione Unidos, Boletin Semaxnal, III (Dec. 9, 1947), 762-766, 781.]

"Specialization and Universal Values in General International Organization," in Lyman Bryson,
Louis Finkelstein and R. M. MacIver, eds., Approaches to Group Understanding, Sixth Conference on Science, Philosophy and Religion, New York, Harper, 1947, 207-217.

"The United Nations Charter and the Prevention of War," Bulletin of the Atomic Scientists. III (Feb. 1947), 57-58,61.

"The Universities and the World Order," Bulletin of American Association of University Professors, XXXIII (Spring 1947), 43-54.

\section{8}

"International Relations" (of China) in There is Another China. Essays and Articles for Chang Po-ling of Nankai, New York, Columbia University Press, 1948, 51-61.

"Measurement of Variations in International Tensions," in Lyman Bryson, Louis Finkelstein and R. M. MacIver, eds., Learning and World Peace. Eighth Conference on Science, Philosophy and Religion, New York, Harper, 1948, 54-62.

"The Military and Foreign Policy," in Jerome G. Kerwin, ed., Civil-Military Relationships in American Life. Walgreen Foundation Lectures, University of Chicago Press, 1948, 116-136.

"On the Application of Intelligence to World Affairs," Bulletin of the Atomic Scientists. IV (August 1948), 249-252.

"Recent Trends in the Evolution of the United Nations," International Organization. World Peace Foundation, II (Nov. 1948), 617-63I.

\section{9}

"Letter on Tensions Project," UNESCO, International Social Science Bulletin, I (Winter 1949), 22-23,100-101.

"Method in the Study of War," World Politics. I (Jan. 1949), 243-256.

"Modern Technology and the World Order," in W. F. Ogburn, ed., Technology and International Relations, Harris Foundation Lectures, University of Chicago Press, 1949, 174198.

"Peace Symposium," United Asia. II (Aug. 1949), 17-29.

"Political Action for World Government, Amending the United States Constitution, Amending and Developing the United Nations Charter," Common Cause, II (June 1949), 407-412.

"Recent Developments in Political Science in the United States," in Political Science in German Universities, Abstract of Conference held at Waldleiningen, (Sept. 10-11, 1949; Frankfurt), 58-63. 
"Relationship between Different Categories of Human Rights," in Human Rights, Comments and Interpretations, a Symposium edited by UNESCO with an introduction by Jacques Maritain, Alan Wingate Publisher, London, 1949, pp. 143-51. (Trans. Autour de la nouvelle declaration des droits de l'homme, textes reunis par l'UNESCO, Sagittaire, Paris, 1949, pp. 118-24.

"Representation in a World Legislature," Common Cause, III (Sept. 1949), 7277.

\section{0}

"American Policy Toward Russia," World Politics, II (Summer 1950), 463-481.

"The Importance of the Study of International Tensions," UNESCO, International Social Science Bulletin, II (Spring 1950), 90-103.

"Political Science and World Stabilization," Presidential Address, American Political Science Association, Am. Pol. Sci. Rev., XLIV (March 1950), $1-13$.

"The Problem of Establishing and Maintaining a Stable World Society," in Lyman Bryson, Louis Finkelstein, and R. M. MacIver, eds., Perspectives on a Troubled Decade, Tenth Symposium on Science, Philosophy and Religion, New York, Harper, 1950, 279-289.

"Some Reflections on War and Peace," American Journal of Psychiarry. CVII (Sept. 1950), 161-169.

\section{1}

"Constitutionalism and World Politics," James Lecture, University of Illinois Bulletin, XLIX (Dec. 1951), No. 32.

"International Law and Power Politics," Measure, Il (Spring 1951), 123-145.

"The Nature of Conflict," Western Political Quarterly, IV (June 1951), 193-209.

"The Significance of the International Political Science Association," (Presidential Address) UNESCO. International Social Science Bulletin, III (Summer 1951), 275-280. [Reprinted, Bulletin of the Nagpur University Political Science Association (1950-1951), 1-8.]

\section{2}

"Experience in Transnational Activities and Organizations," in Lyman Bryson, Louis Finkelstein, H. D. Lasswell, and R. M. MacIver, eds., Foundations of World Organization, A Political and Cultural Appraisal. Eleventh Symposium of Conference on Science, Philosophy and Religion,
New York, Harper, 1952, 1-8.

"Realism and Idealism in International Politics," World Politics, V (Oct. 1952), 116-128.

\section{3}

"Economic and Political Conditions of World Stability," The Journal of Economic History. XII (Fall 1953), 363-377.

"Freedom and Authority in International Organization,"' in Lyman Bryson, Louis Finkelstein, R. M. MacIver, and Richard McKeon, eds., Freedom and Authority in Our Time, Twelfth Symposium on Science, Philosophy and Religion, New York, Harper, 1953, $169-182$.

"Law and Politics in the World Community," in George A. Lipsky, ed., Law and Politics in the World Community, Essays on Hans Kelsen's Pure Theory and Related Problems in International Law, Berkeley, University of California Press, 1953, 3-14.

Papers submitted to 2nd Conference, International Political Science Association, The Hague, Sept. 1952, resuméd in UNESCO, International Social Science Bulletin, V (1953), 51-74.

\section{4}

"Human Rights and Charter Revision," Annals, CCXCVI (Nov. 1954), 46-55.

"Moral Standards in Government and Politics," Ethics, LXIV (April 1954), 157-168.

"The Psychological Approach to War and Peace," India Quarterly, New Delhi, X (Jan.-March 1954), 23-31.

"Symbols of Nationalism and Internationalism," in Lyman Bryson, Louis Finkelstein, R. M. MacIver, and Richard McKeon, eds., Symbols and Values: An Initial Study, 13th Symposium of the Conference on Science, Philosophy and Religion, New York, Harper, 1954, 383-403.

\section{5}

"International Organization and Peace," Western Political Quarterly, VIII (June 1955), 149-165.

Letter on Kenneth Boulding Article, Bulletin of the Research Exchange on Prevention of War, III (July 1955), 77-78.

"The Peaceful Adjustment of International Relations: Problems and Research Approaches," Journal of Social Issues, XI (1955), 3-12.

\section{6}

"Equality in International Law and International Relations," in Lyman Bryson, Clarence H. Faust, 
Louis Finkelstein, and R. M. Maclver, eds., Aspects of Human Equality, 15th Symposium of the Conference on Science, Philosophy and Religion, New York, Harper, 1956, 335-366.

\section{7}

"Design for a Research Project on International Conflicts and the Factors Causing Their Aggravation and Amelioration," Western Political Quarterly, X (June 1957), 263-275.

"Development of World Public Opinion and Transnational Communication," in Arthur N. Holcombe, ed., Strengthening the United Nations, 10th Report of the Commission to Study the Organization of Peace, New York, Harper, 1957.

"International Conflict and the United Nations," World Politics, X (Autumn 1957), 24-48.

"The Mode of Financing Unions of States as a Measure of their Degree of Integration," International Organization, XI (Winter 1957), 30-40.

"Project for a World Intelligence Center," Journal of Conflict Resolution, I (March 1957), 93-97.

"Research in International Law," in Wm. W. Bishop, ed., Lectures on International Law and the United Nations, University of Michigan Law School, 8th Summer Institute, June 1955, Ann Arbor, Mich., 75-82.

"The Status of Communist China," Journal of International Affairs (Columbia University), XI (Summer 1957), 171-186.

"The Value for Conflict Resolution of a General Discipline of International Relations," Journal of Conflict Resolution, I (March 1957), 3-8.

\section{9}

"The Role of Law in the Organization of Peace," in Arthur N. Holcombe, ed., Organizing Peace in the Nuclear Age, 11 th Report of the Commission to Study the Organization of Peace, New York, New York University Press, 1959, 27-49.

\section{0}

"Empires and World Governments before 1918," Current History, (August 1960), 65-74.

\section{1}

"Sovereignty and International Cooperation," in J. S. Bains, ed., Studies in Political Science, in honor of Dr. J. C. Chacko, Bombay, Asia Publishing House, 1961, 14-37.

"Western Diplomacy Since 1945," Annals, CCCVI (July 1961), 144-153.

\section{2}

"Espionage and the Doctrine of Non-Intervention in International Affairs," in Roland J. Stander, ed., Essays on Espionage in International Law, Ohio State University Press, 1962, 3-28.

"The Future of the United Nations," Political Science Annual, University of Jabalpur, (1962), 1-5.

"Legal Obstacles to Universal Membership of the UN," in Arthur N. Holcombe, ed., A Universal United Nations, 15th Report of the Commission to Study the Organization of Peace, New York, July 1962, 51-58.

"Maintaining Peaceful Coexistence," in Quincy Wright, William M. Evan, and Morton Deutsch, eds., Preventing World War III, Some Proposals, New York, Simon and Schuster, 1962, 410-441.

"Peaceful Change and International Law," Political Science Annual, University of Jabalpur, (1962), 14-18.

"Policies for Strengthening the United Nations," in James Roosevelt, ed., The Liberal Papers, Chicago, Quadrangle Books, 1962, 313-340.

"The United Nations and the Congo Crisis," The Journal of Sociology, University of Jabalpur, (1962), 14-24.

\section{3}

"Conditions of Successful Disarmament," Journal of Conflict Resolution, VII (Sept. 1963), 286-292; Journal of Arms Control, I (Oct. 1963), $380-386$.

"The Decline of Classic Diplomacy," Journal of International Affairs, Columbia University, XVII (Winter 1963), 18-28.

"The Projected European Union and American International Prestige," Annals, CCCXLVIII (July 1963), 132-140.

\section{4}

"Development of a General Theory of International Relations," in Horace V. Harrison, ed., The Role of Theory in International Relations, New York, Van Nostrand, 1964, 15-44.

"History of the Concept of War," in Indian Year Book of International Affairs, Madras, XIII (1964), 116-147.

"Political Science and Politics in the United States," in The Turkish Year Book of International Relations, Ankara University, 1964, 47-58. 
1965

"The Escalation of International Conflict," Journal of Conflict Resolution. IX (Dec. 1965), 434-449.

"Peace Keeping Operations of the United Nations," International Studies, VII (Oct. 1965), 169-204.

\section{7}

"Development of International Law as a Discipline," in Peter A. Toma and Andrew Gyorgy, eds., Basic Issues in International Relations. Boston, Allyn and Bacon, 1967, 12-21.

"The Social Sciences and Conflicts and Concentration," in The Role of the Universities in the Quest for Peace, Oysterbay, New York, 1967, 8-14.

\section{8}

"International and Civil Strife," Proc. International Peace Research Assoc. Netherlands, XI (1968), 369-372.

"Non-military Intervention," in Karl Deutsch and Stanley Hoffman, eds., The Relevance of Interna- tional Law, essays in honor of Leo Gross, Cambridge, Mass., Schenkman Publishing, 1968. 5-19.

\section{9}

"Conflict Resolution and the United Nations Peace-keeping Forces," Towson State Journal of International Affairs (Baltimore, Md.), III (Spring 1969), No. 2, 97-110.

"Empires and World Government before 1918," Current History, XXXIX (August 1969), No. 228, 65-74.

\section{0}

"How Hostilities Have Ended: Peace Treaties and Alternatives," Annals, CCCXCII (Nov. 1970), 51-61.

"Legal Limits on the Continental Shelf," in Richard N. Swift, ed., The UN and the Bed of the Sea (II), 2 Ist Report of the Commission to Study the Organization of Peace, New York, 1970, 34-38. 